\title{
Social influences in cross-border entrepreneurial migration policy
}

\section{Daria Kautto}

Department of Management Studies, School of Business, Aalto University, Ekonominaukio 1, 02150 Espoo, Finland

\section{Correspondence:}

D Kautto, Department of Management Studies, School of Business, Aalto University, Ekonominaukio 1, 02150 Espoo, Finland. Tel: +358-505-692-898; e-mail: daria.kautto@aalto.fi
Received: 14 September 2018

Revised: 29 September 2019

Accepted: 7 October 2019

Online publication date: 8 November 2019

\begin{abstract}
This paper addresses the possibilities for public policy to stimulate the entrepreneurial perceptions of individuals by leveraging micro-level social influences produced by migrant entrepreneurs. As opposed to the conventional stand according to which entrepreneurial ecosystems can be stimulated by financial, regulative, cognitive and normative mechanisms of influence, the present study suggests that socio-psychological influences enacted by exogenous policy intervention can be used as a mechanism for shifting the entrepreneurial perceptions of individuals. Cross-border entrepreneurial migration is proposed as an instrument for enacting these sociopsychological influences and enabling public policy to benefit from the distinctively different entrepreneurial behaviors of migrant entrepreneurs and local individuals in the host country. The study offers substantial policy implications by extending the theoretical reasoning guiding the stimulation of entrepreneurial ecosystems through public policy intervention, providing discussion of opportunity perception in cross-border context, and offering an alternative socio-economic perspective on the role of migrant entrepreneurs in the economic life of host countries.

Journal of International Business Policy (2019) 2, 397-4I2.

https://doi.org/ | 0.1057/s42214-019-00040-x
\end{abstract}

Keywords: social influences; entrepreneurial migration; entrepreneurship policy; entrepreneurial attitudes; perceived behavioral control

The online version of this article is available Open Access

\section{INTRODUCTION}

International business and entrepreneurship research converges on the idea that social influences play an important role in international and domestic entrepreneurial activity. It has been suggested that social influences in international business transmitted through interorganizational and personal social networks create strategic value for the process of internationalization and increase the speed and performance of internationally operating firms (Johanson \& Mattsson, 1988; Johanson \& Vahlne, 2009; Iurkov \& Benito, 2018). In entrepreneurship, the influences provided by the presence of entrepreneurial peers are associated with a higher likelihood that other individuals will undertake venture creation (Kacperczyk, 2013). In international entrepreneurship, which fuses the literature 
of international business and entrepreneurship, social embeddedness is emphasized as a driving force behind the identification and enactment of international entrepreneurial opportunities (Oviatt \& McDougall, 2005; Coviello, 2006; Ellis, 2011).

Regardless of the compelling arguments that social influences have an impact on the likelihood of venture formation, its geographic scope and the outcomes of operations, there is, however, limited scientific knowledge about the opportunities for leveraging these influences across national borders to improve the quality of entrepreneurial activities through public policy. International business and entrepreneurship policy research has predominantly focused on the impact of financial, regulatory, normative, and cognitive mechanisms on the international and domestic entrepreneurial activities of firms (Lerner, 2012; Eberhart, Eesley, \& Eisenhardt, 2017; Hiatt, Sine, \& Tolbert, 2009). While there is evidence that these mechanisms effect beneficial change in elements of the entrepreneurial ecosystem such as the quality of the business environment and its actors, they have had less impact on entrepreneurial culture and attitudes to entrepreneurship, i.e., entrepreneurial perceptions (Lundström \& Stevenson, 2005). This creates a need to introduce socio-psychological mechanisms of policy intervention, which might be better suited to stimulation of change in the perceptions and attitudes of individuals. In addition, existing non-policy research on the role of social influences in international and domestic entrepreneurship has mostly focused on the creation of new organizations and the establishment of new international operations as a unit of analysis. Studies on the dependency between entrepreneurial peer presence and the dynamics of new venture formation (e.g., Kacperczyk, 2013; Nanda \& Sørensen, 2010), social embeddedness and the initiation of foreign market operations (e.g., Manolova, Manev, \& Gyoshev, 2010), and social referencing as a driver of international expansion, are examples of this stream of research. Consequently, there has been less exploration of the role of social influences in individuallevel entrepreneurial behavior, more specifically the micro-level changes that could occur within entrepreneurs themselves.

Thus, the purpose of this conceptual paper is to develop a theoretical argument addressing the possibilities for public policy to stimulate the entrepreneurial perceptions of individuals by leveraging the micro-level social influences produced by migrant entrepreneurs. The study suggests that socio- psychological influences enacted by exogenous policy intervention can be used as a mechanism for shifting the entrepreneurial perceptions of individuals. Entrepreneurial perceptions act as a direct antecedent of entrepreneurial intention and consequently entrepreneurial behavior. Hence, it has been suggested that positive shifts in them improve both the magnitude and the quality of entrepreneurial activity in the economy. Due, however, to the pathdependency of entrepreneurial perceptions, they are known to be particularly difficult to shift (Arenius \& Minniti, 2005). As the entrepreneurial perceptions of individuals tend to be homogenized within one socio-economic system, social influences from outside this environment need to be exploited to change these perceptions. The paper proposes that crossborder entrepreneurial migration is an instrument that could enact these socio-psychological influences and enable public policy to benefit from the distinctively different entrepreneurial behaviors of migrant entrepreneurs and local individuals in the host country.

Drawing on a set of classic social psychology theories, the study theorizes that, as behaviors can be learned through observation (Bandura, 1977) and observed behaviors can trigger a change in attitudes and beliefs (Zimbardo \& Leippe, 1991), purposefully designed observation of entrepreneurial behavior of migrant entrepreneurs will produce a change in entrepreneurial perceptions, more specifically in the attitudes and perceived behavioral control of the exposed local individuals. The change could be triggered by one of two influence pathways. The first pathway goes through the observed behavior of migrant entrepreneurs and results in a change in attitudes and perceived behavioral control in the form of a feedback process. It is associated with mechanisms of socio-psychological influence such as observational learning (Bandura, 1977) and cognitive dissonance (Festinger, 1954). The second pathway goes through direct exposure to the contrasting attitudes and opinions of migrant entrepreneurs and results in attitude change. This pathway is associated with the mechanism of social comparison (Festinger, 1954). Beyond the personal characteristics of the observers, the likelihood of perception change through either of these mechanisms depends on a set of characteristics attributed to the observed models by local individuals (Bandura, 1977). The study hypothesizes that different types of migrant entrepreneurs - international, returnee, and regional - possess a variety of model characteristics such as unconventional behavior, power, expertise, 
credibility, and linguistic and cultural backgrounds. If so, each type of migrant entrepreneur would be able to reinforce either one dominant micro-level socio-psychological mechanism of change or a combination of mechanisms. The study suggests that observation of the behavior of returnee entrepreneurial migrants is particularly important. Based on the analysis of the model characteristics that attract attention of the local observers (Sutherland, Cressey, \& Luckenbill, 1992) to attitudes and behavior of entrepreneurial migrants, the study proposes that returnee entrepreneurial migrants serve as the most reliable driver of attitude and perceived behavioral control change in all three mechanisms of socio-psychological influence. Exposure to the behavior and attitudes of international entrepreneurs in turn acts as an efficient driver for the promotion of unconventional attitudes and innovative behaviors.

The study is unique in developing a theoretical argument that, apart from the stimulation of entrepreneurial activities with financial, regulatory, normative, and cognitive mechanisms of influence, public policy has the potential for leveraging the socio-psychological influences produced by migrant entrepreneurs in a cross-border setting. The proposed theory expands the socio-economic role of migrant entrepreneurs from that of job creators (Kerr \& Kerr, 2018; Kauffman Foundation, 2015), capital investors (Flisi \& Murat, 2011; Mullings, 2011), knowledge providers (Levin \& Bernard, 2013), and institutional change agents (Williams, 2018) to socio-psychological role models who are able to stimulate micro-level changes in the entrepreneurial perceptions and attitudes of local individuals. The notion of immigrant role models is new to international business and migration policy research, as immigrants themselves have conventionally been approached as objects of the influence of role models in the host country (Aldrich \& Waldinger, 1990; Saxenian, 1999; Contin-Pilart \& Larraza-Kintana, 2015; Mayer, Harima, $\&$ Freiling, 2015). Although the literature on diaspora entrepreneurship acknowledges the role of diaspora in inspiring home-country entrepreneurs (Williams, 2018), the mechanisms through which migrant role models exert their influence, the relative effectiveness of social influences produced by different types of entrepreneurial migrants, and the ability of public policy to benefit from these influences have not been previously studied.

The rest of the paper is organized as follows. Section "Policy framework of entrepreneurial activities" outlines "the building blocks of entrepreneurial activities in the economy from the policy perspective" and reviews existing public policy interventions affecting the demand and supply sides of entrepreneurship. It then discusses entrepreneurial perceptions as an element of a framework that is one of the most difficult to change from the policy perspective. Section "Entrepreneurial perceptions and attitudes" conceptualizes the factors contributing to entrepreneurial perceptions using a well-established theory of planned behavior (Ajzen, 1985). The ways to impact these factors through social influence are then derived in Section "Social influences in entrepreneurial perceptions and attitudes" on the basis of a set of classic social psychology theories: social learning theory (Bandura, 1977), cognitive dissonance theory (Festinger, 1954), and social comparison theory (Festinger, 1954). Section "Entrepreneurial migration as an instrument for enacting social influences" proposes that intervention through entrepreneurial migration policy can be used to enact the desired social influences and consequently shift the entrepreneurial perceptions of individuals. Finally, Section "Limitations and policy considerations" discusses the limitations and policy considerations related to the theorization.

The study offers substantial policy implications by extending the theoretical reasoning that guides the stimulation of entrepreneurial ecosystems through public policy intervention. It develops a theoretical argument for the potential of public policy to leverage micro-level socio-psychological influences in efforts to affect the entrepreneurial perceptions of individuals in a local economy. Moreover, the study provides an alternative socio-economic perspective on the role of migrant entrepreneurs in the economic life of the host countries.

\section{POLICY FRAMEWORK OF ENTREPRENEURIAL ACTIVITIES}

The level of entrepreneurial activities in an economy is determined by the interaction of the demand (product market) and supply (labor market) sides of entrepreneurship (Audretsch, Grilo, \& Thurik, 2007). Together with resource availability and individual capabilities, they lead to the formation of entrepreneurial intention and consequently result in entrepreneurial behavior (Verheul, Wennekers, Audretsch, \& Thuril, 2001) (Figure 1). The proposed policy framework of entrepreneurial activities builds on earlier conceptualizations of 
Figure 1 A policy framework for entrepreneurial activities.

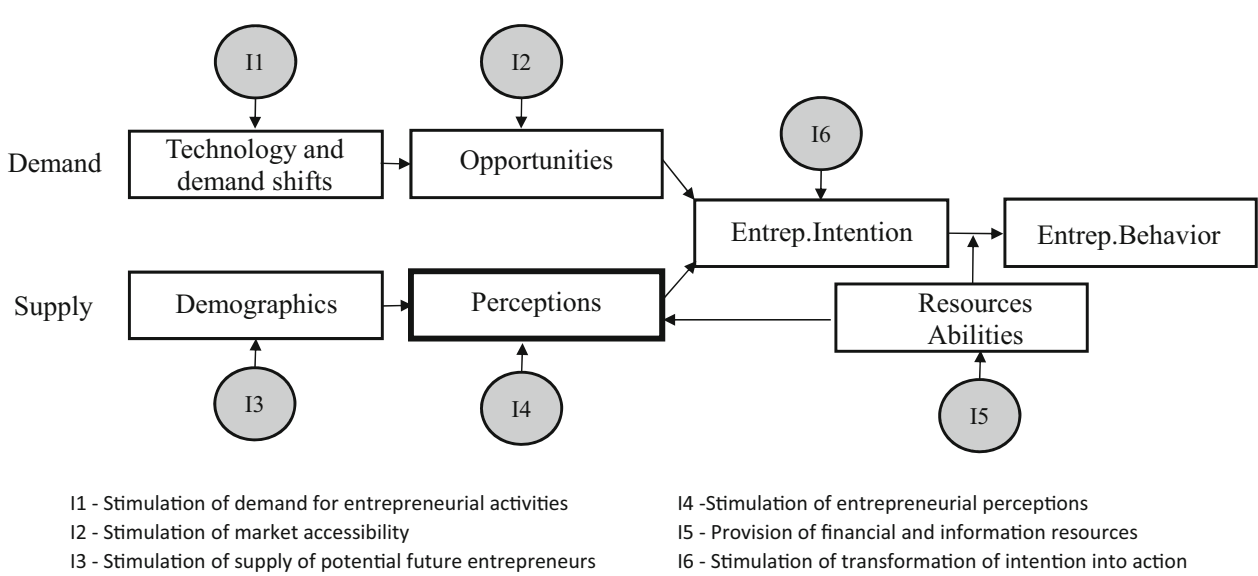

entrepreneurial activities in the economy provided by Verheul et al. (2001), Thurik, Wennekers, \& Uhkander (2002), and Audretsch et al. (2007). The subsequent discussion of the framework provides the specifics of entrepreneurship policy measures performed in a cross-border setting.

From the demand-side perspective, technology and shifts in demand lead to formation of the carrying capacity of the market in terms of available business opportunities (Verheul et al., 2001) (e.g., the development of artificial intelligence provides opportunities for knowledge extraction from massive datasets or the rise in demand for non-animalbased products leads to exponential growth of the vegan market). From the supply-side perspective, various demographic characteristics (e.g., size and composition of the population, density, or urbanization rate) define the entrepreneurial capacity of the labor market in terms of perceptions of entrepreneurship and preferences for it (Verheul et al., 2001). For example, the propensity to become an entrepreneur is significantly higher in countries with a lower workforce median age (Liang, Wang, \& Lazear, 2016) or among individuals with immigrant backgrounds (Kerr \& Kerr, 2018).

If the necessary resources and individual capabilities are present, the identification of business opportunities by individuals with favorable perceptions of entrepreneurship leads to the formation of entrepreneurial intention (Verheul et al., 2001). An individual with entrepreneurial intention first identifies a so-called third-person opportunity (a potential opportunity for someone in the marketplace), then conducts a feasibility and desirability assessment, and finally decides whether to engage in entrepreneurial behavior in the form of opportunity exploitation (McMullen \& Shepherd 2006).
Both product (demand-side) and labor (supplyside) markets for entrepreneurship could either regulate themselves or become objects of public policy intervention (Audretsch et al., 2007). Decisions to intervene in the national economy depend on the perception of the government regarding deviation of the actual entrepreneurship level from the "equilibrium" (Verheul et al., 2001). The "equilibrium" in this case is defined as a long-term optimal level resulting from demand-side forces; technological developments and changes in the market structure are examples of such forces. Irrespective of the magnitude of the perceived deviation, the judgment of the government regarding the existing disequilibrium is always an approximation and is subjective in nature (Verheul et al., 2001).

To effect change in the actual level of entrepreneurship activity in the economy, the government could perform policy interventions directed at different elements of the demand or supply sides of entrepreneurship (Audretsch et al., 2007). Thus, each element of the policy framework of entrepreneurial activities (Figure 1) could be viewed from the perspective of potential policy mechanisms (i.e., causal relationships explaining how and why a policy will have an impact on the targeted outcome) and policy instruments (i.e., actual tools for implementing policies) for conducting an intervention. The groups of policy interventions corresponding to each of the framework elements are discussed below in more detail (marked I1-I6 in Figure 1).

The first group of the policy interventions (I1) is aimed at stimulating demand for entrepreneurial activities through the promotion of technology development and shifts in demand caused mostly by income changes. Subsidies for research and 
development activities, public science and crossborder research collaboration funding (McMillan, Narin, \& Deeds, 2000), as well as income policy instruments affecting wealth accumulation and income disparity, are the potential tools to use within this group. The second group of policy interventions (I2) is directed at stimulating market accessibility through the use of competition legislation, establishment and bankruptcy legislation, protection of property rights, and labor market legislation (e.g., lowering barriers to migrant worker recruitment). The third group (I3) seeks to influence a number of potential future entrepreneurs. Their supply could be affected directly through immigration or regional development (urbanization) policies, or indirectly, for example, through education, fiscal or fertility policies, which affect population age structure in the longer run. The fourth group (I4) aims to affect the entrepreneurial perceptions of individuals by fostering entrepreneurial culture. Formal training and the media could be used for this purpose. The fifth group (I5) seeks to provide financial (cash grants, interest-free loans, loan guarantees or tax breaks) and informational (business information and education) resources to reinforce positive attitudes to entrepreneurship and enable engagement in entrepreneurial behavior. The policy actions within this group are often directed at diaspora and returnee entrepreneurs considering investments in their countries of origin. Finally, the sixth group (I6) of policy interventions is aimed at transforming entrepreneurial intention into actual entrepreneurial behavior. In other words, these policy measures are aimed at affecting the choice of entrepreneurship as opposed to other options (paid employment or unemployment). Taxation, social security benefits, labor market legislation and bankruptcy policy could be used for this purpose.

The policy instruments associated with stimulation of market access (I2) and provision of financial and informational resources (I5) are utilized most frequently for promoting cross-border entrepreneurial activity. While looking for the direct investment from abroad to start new businesses, governments may target their efforts at several distinctive groups of migrants: diaspora, returnee, and international entrepreneurs. Both diaspora and returnee entrepreneurs are often driven by emotional connections with the country of origin in their economic activity (Williams \& Efendic, 2019). These emotional ties encourage them to contribute economically and socially to their home countries; their motives are not entirely financial (Nielsen \& Riddle, 2010). Thus, the policies targeting these two groups of migrants aim mostly at increasing their pre-defined investment interest in the domestic economy by easing navigation of the local institutional environment, providing access to the market and operational information, and mitigating the financial risk associated with a potentially unfavorable local business environment (Williams, 2018). So-called "diaspora institutions" (Gamlen, 2014), matching funding schemes, and "one-stop-shops" (Nielsen \& Riddle, 2010) are respectively used to address these purposes.

As opposed to diaspora and returnee entrepreneurs, international entrepreneurial migrants do not possess emotional ties to locations where they may pursue entrepreneurial opportunities and thus the economic reasons play a primary role in their location choices. The quality of the institutional environment, knowledge spillovers, and access to market and resources shape their initial country assessment (Efendic, 2016). In addition, the international experience and high geographic mobility of this group of migrants, and often also a global market for their business ideas, allow them to operate within global ecosystems of opportunity seekers (Reuber, Knight, Liesch, \& Zhou, 2018), where governments are substantially challenged to attract and retain the best entrepreneurial talent from abroad. In order to be internationally competitive, the policy measures are focused primarily on provision of a seamless entrepreneurial migration experience associated with removal of legislative (I2), financial (I5), and informational (I5) barriers to entrepreneurial migration (Efendic, 2016). This comprehensive approach is often associated with the establishment of public start-up programs that promote entrepreneurial migration among the founders of new international highgrowth ventures and make them eligible for startup visas following a governmental vetting process.

While public policy makes intensive use of policy interventions directed at stimulating market accessibility and provision of financial and informational resources to entrepreneurial migrants, direct interventions in entrepreneurial perceptions in the cross-border entrepreneurial context remain obscure. Compared with all other elements of the policy framework for entrepreneurial activities, policy interventions in entrepreneurial perceptions (group I4) are seen as the most difficult to accomplish. As Arenius \& Minniti (2005, pp. 243-244) put it, perceptual factors "could not be easily changed 
by exogenous interventions, such as, for example, government policies. [...] They are path-dependent and, as a result, do not change or change very slowly." This is because entrepreneurial perceptions, often referred to as entrepreneurial culture in policy discussions, are partially rooted in social norms. While social norms are difficult to change in general (Parsons' theory of socialization, 1951), it is also challenging to affect them with exogenous financial, regulative, cognitive or normative mechanisms of policy influence (Audretsch, et al. 2007; Verheul et al., 2001). For example, OECD (2000, p. 176) policy recommendations specify that individual entrepreneurial perceptions are rooted in cultural and family norms as well as local traditions and are thus difficult to modify.

Public policy has made attempts to involve diaspora networks in business advice and mentorship in their home countries in order to affect the prevailing social norms related to entrepreneurial activity (Williams, 2018). Entrepreneurship policy research has, however, largely overlooked the fact that social norms are not the only constituting element of entrepreneurial perceptions. Ajzen's (1985) classic theory of planned behavior suggests that, in addition to social norms, perception consists of two additional elements: attitudes towards behavior and perceived behavioral control. Thus, a deeper investigation of the structure of entrepreneurial perceptions and attitudes and the mechanisms to induce change in them would create new opportunities for public policy to stimulate the supply side of entrepreneurship and the entrepreneurship ecosystem in general. The next section discusses the extended structure of entrepreneurial perceptions and attitudes (the box labeled "Perceptions" in Figure 1) using a theory of planned behavior and the reasoned-action approach. The possibility to affect entrepreneurial perceptions and attitudes with the social influences provided by migrant entrepreneurs is then derived in sections "Social influences in entrepreneurial perceptions and attitudes" and "Entrepreneurial migration as an instrument for enacting social influences."

\section{ENTREPRENEURIAL PERCEPTIONS AND ATTITUDES}

According to the well-established social psychology theories of planned behavior (Ajzen, 1985) and the reasoned-action approach (Fishbein \& Ajzen, 2010), perceptions of and attitudes towards a certain behavior determine the behavioral intention of an individual. Intention moderated by actual control over the situation, defined by the skills and abilities of the individual, predicts actual behavior. Both perceptions and attitudes are determined by the respective beliefs, which are reinforced through the performed behavior. These structural relationships between behavioral perceptions and attitudes and their antecedents and outcomes are presented in Figure 2.

The theory of planned behavior (Ajzen, 1985) and the reasoned-action approach (Fishbein \& Ajzen, 2010) identify three distinct elements of behavioral perceptions and attitudes: those towards behavior, perceived norms, and perceived behavioral control. Attitudes towards behavior represent the tendency of an individual to respond to a psychological object (in this case, entrepreneurial behavior) with a certain degree of favorableness or unfavorableness. Perceived norms refer to the subjective social norms defining whether a behavior should or should not be performed. Perceived behavioral control represents the degree to which individuals think that they are able to perform a behavior.

Each of these three elements is determined by the respective beliefs (Ajzen, 1985). Behavioral beliefs are defined as a product of belief strength and an estimation of the probability of its occurrence (Fishbein \& Ajzen, 1975). For example, in the case of entrepreneurial behavior, one may be very much afraid of failure (belief strength). Such an outcome is, however, highly unlikely (evaluation of the

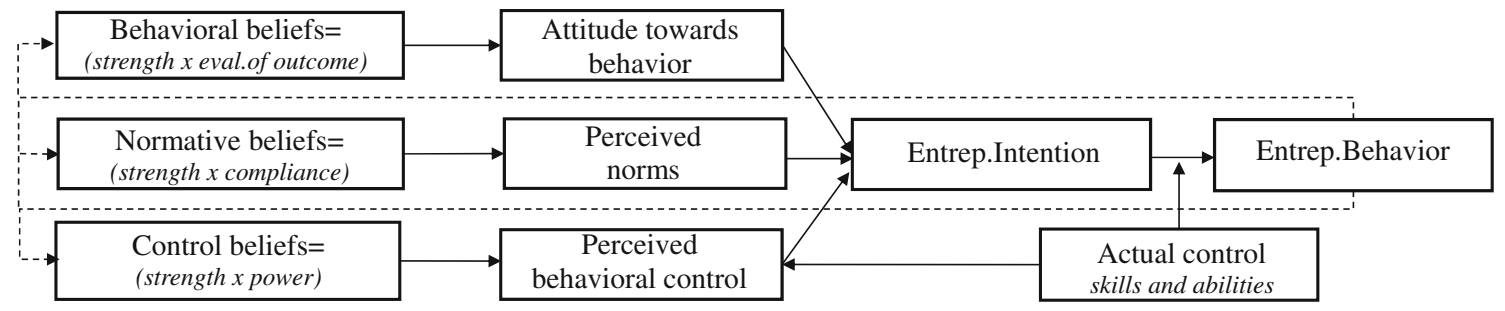

Figure 2 A structural model of the antecedents and outcomes of entrepreneurial perceptions. 
outcome). Normative beliefs are defined as the product of belief strength and compliance with it (Ajzen, 1985). For example, entrepreneurial behavior could be considered a highly unfavorable career choice in a particular society. A particular individual could, however, decide to dissent from this norm. Similarly, control beliefs are defined as the product of the belief strength and perceived power of a particular control factor to facilitate or inhibit performance (Ajzen, 1991). For example, one may strongly believe that having earlier entrepreneurial experience is important for identifying entrepreneurial opportunities (belief strength). A lack of entrepreneurial experience would, however, not prevent individuals from finding a feasible opportunity themselves (inhibiting power). Thus, beliefs related to the consequences of a behavior are defined as behavioral and determine behavioral attitudes, beliefs concerning social attitudes to behavior as normative because they shape perceived social norms, while beliefs concerning resources and opportunities are called control beliefs and determine perceived behavioral control (Ajzen, 1991).

Earlier entrepreneurship policy research has predominantly focused on two elements of the above structural model of entrepreneurial perceptions: perceived norms and actual control over behavior (e.g., Kautonen, Tornikoski, \& Kibler, 2011; Wilson, Kickul, \& Marlino, 2007; Newman, Obschonka, Schwarz, Cohen, \& Nielasen, 2019; Hsu, Burmeister-Lamp, Simmons, Foo, Hong, \& Pipes, 2019) (Figure 2). Two policy mechanisms of influence aimed at stimulating these elements have been proposed (Audretsch et al., 2007). The first, the normative mechanism, is enacted through media communication to influence perceived societal norms related to entrepreneurship. The second, the cognitive mechanism, is enacted through formal entrepreneurial education to influence the skills and abilities of individuals to start a new venture. While both perceived norms and actual control play a significant role in determining entrepreneurial intentions and entrepreneurial behavior, existing meta-analyses of the intention-behavior relationship guided by the theory of planned behavior suggest that up to $86 \%$ of behavioral intention is explained by the attitudes of individuals towards behavior and perceived behavioral control (Webb \& Sheeran, 2006). Thus, stimulation of these two elements, which have been largely overlooked in policy research, could be the most efficient way of affecting change in entrepreneurial perceptions in a given economy.

Moreover, it should be noted that attitudes towards entrepreneurial behavior and perceived behavioral control become highly contextualized and relative measures in the contemporary global ecosystems for entrepreneurship (Reuber et al., 2018). Given that individuals who are internationally mobile can compare different environments for entrepreneurship, this impacts their attitudes to entrepreneurship as well as the degree to which they think they would be able to perform entrepreneurial behavior at a particular location. Thus, the perception of opportunity by the same individual may vary significantly depending on the institutional conditions and environmental cues received at the specific location (Williams \& Efendic, 2019; Krasniqi \& Williams, 2018) and could in turn influence the perception of opportunity of the others. The next section discusses potential mechanisms of influence by explaining how and why attitudes towards behavior and perceived behavioral control could be changed.

\section{SOCIAL INFLEUNCES IN ENTREPRENEURIAL PERCEPTIONS AND ATTITUDES}

Behavioral and cognitive theories in the field of social psychology suggest that social influences can change the attitudes and perceptions of individuals enormously (Zimbardo \& Leippe, 1991). Depending on the mechanism of social influence, the change could occur either as a result of performed or observed behavior, as a feedback process, or as a result of direct exposure to the attitudes of others.

The first path to attitude and perception change goes through the actual behavior of an individual or observation of the behavior of others (Zimbardo \& Leippe, 1991). According to the foundational work of Bandura (1977), this path is suitable for changing both the attitudes to behavior, in this specific case entrepreneurship, and the perceived behavioral control. If the behavior is performed by the individual themselves, the response of the environment to this behavior will control the change (Zimbardo \& Leippe, 1991). A positive response will reinforce the behavior, strengthen existing attitudes, and contribute to growth in the perceived behavioral control of the individual. A negative response may result in a change in the behavior or in attitudes and weaken control beliefs. However, altering the attitudes and perceptions of individuals through direct experience alone would 
be a very laborious process. The classic social cognitive learning theory, introduced by Bandura (1977), suggests that virtually all behaviors and attitudes learned through direct experience could also be learned by observing others (Bandura, 2016). This mechanism is called "observational learning" or "social modeling" (Bandura, 1977). Observation of the behavior of other people can result in the learning of new behaviors; acting together, the outcomes of these behaviors can affect the perceived behavioral control of the observer. As opposed to learning through actual performed behavior, observational learning could take place without experiential reproduction or direct reinforcement. Observing others affects motivation and perceived behavioral control by conveying the functional value of the observed behavior. Actions taken by others to achieve desired outcomes through their behavior create outcome expectancies that serve as a positive incentive for action of our own. People could also change or acquire lasting attitudes by observing the emotional arousals of others. Seeing others being afraid of doing something would most likely also make us afraid to do the same thing. However, seeing the enjoyment of others in taking a risk would most likely encourage us to do likewise. Observational learning plays a particularly important role in situations where behavioral attitudes and perceived behavioral control are related to a new, uncommon or still socially unaccepted behavior (Bandura, 1977) such as entrepreneurship.

Another mechanism of social influence, which also functions through the feedback loop from behavior to beliefs and further to attitudes and perceptions, is cognitive dissonance (introduced by Festinger, 1954 in his classic theory of cognitive dissonance). As opposed to observational learning where changes in perceived behavioral control and attitudes are caused by external vicarious reinforcement, the mechanism of cognitive dissonance suggests that individuals may change attitudes because of an internal need for consistency. In situations where cognitions - bits of knowledge, attitudes and beliefs - contradict each other in the mind of individuals, they aim to restore consonance by changing either the behavior or the attitudes. However, it is not always possible to alter the behavior that causes inconsistency, particularly if this behavior is performed by others. Although such behavior cannot be changed or revoked, the beliefs or attitudes inconsistent with it can be changed, as in "I probably should not be afraid of taking a risk as these guys do it daily without even blinking an eye." The distinguishing feature of the cognitive dissonance theory is that the rationale for the dissonance between the behavior ("They take risks all the time") and the attitude ("I am afraid of taking a risk") is not attributed to the situation ("They take risks because they can afford it but I cannot") but rather to the persons themselves ("If they take risks all the time and I don't, maybe I'm over-careful"). Thus, the observed behavior produces an internally-justified attitude change. In addition to the first path that leads to changes in attitude and perception through actual and observed behavior, there is also a second path that results in changes in attitude through direct exposure to the attitudes of others (Zimbardo \& Leippe, 1991). Several socio-psychological theories - social comparison theory, elaboration likelihood theory, social judgment theory, and other theories of persuasion and informational conformity - have addressed this route to attitude change from slightly different perspectives. As the present study focuses on pursuing influence by exposure to the attitudes of others instead of by deliberate persuasion, we have adopted a theory of social comparison to explain changes in attitude effected through exposure to the attitudes of others.

The social comparison mechanism introduced by the foundational work of Festinger (1954) suggests that people have a basic need to evaluate their attitudes and behaviors against others and confirm that they are correct. This provides a sense of control and a feeling of competence. Thus, driven by the need to be correct and obtain social approval, individuals conform to the beliefs and/ or behaviors of others, particularly in new and ambiguous settings. This conformity could be driven by either normative or informational social influence. Normative social influence implies the adoption of the prevailing standard of behavior in order to achieve a positive affect: liking, respect, or acceptance. However, the resulting change in behavior is usually transient and has no lasting effect on the actual attitudes and beliefs of the individual. As opposed to normative influence, informational social influence implies adopting the attitude and consequently the behaviors of others out of a need to know whether one is correct, particularly if the situation is novel or an unambiguous assessment thereof is not possible. The need to be correct motivates individuals to compare their attitudes, beliefs or opinions (verbalized attitudes and beliefs) with those of others. 
This comparison could result in either a reinforcement of existing attitudes, if proof of their correctness is found, or cause a change in attitude if there is sufficient justification for a contradictory opinion on the part of others. The informational social influence could be exemplified with the following line of thought: "I think it's difficult to start a business which could be scalable abroad, so I'm not particularly fond of this idea. But those who've succeeded in doing it before think it's a lot of fun. May be I should listen to them and change my opinion." When influenced by informational cues from the environment, individuals may revisit their cognitive structure and alter their attitude to a particular behavior at the cognitive level.

In sum, three major socio-psychological mechanisms are suitable for changes in attitude and perception. The first two - observational learning and cognitive dissonance - alter attitudes and perceptions through the actual and observed behavior of individuals. Observational learning primarily contributes to improvements in perceived behavioral control. Cognitive dissonance causes shifts in the attitudes of individuals when unconventional behavior is observed. The third mechanism - social comparison - results in attitude change due to direct exposure to the attitudes and opinions of others. Social comparison could result in attitude change through the mechanism of informational conformity.

Based on these premises, the present study suggests that social influences enacted by exogenous policy interventions can shift the entrepreneurial perceptions and attitudes of individuals through three distinctive mechanisms of social influence: observational learning, cognitive dissonance, and social comparison. As interaction between the representatives of at least two social groups with distinctively different behaviors and attitudes serves as a precondition for the activation of the above-mentioned mechanisms, entrepreneurial migration can enable public policy to benefit from the above-mentioned socio-psychological influences. The change effects achieved in the entrepreneurial perceptions of the local population through observation of the behaviors and adoption of the attitudes of entrepreneurial migrants could be purposefully manipulated in a policy intervention and utilized in entrepreneurship policy design. The next section provides a detailed discussion of the rationales for the demonstration of respective socio-psychological influences by different types of entrepreneurial migrants based on their dominant model characteristics.

\section{ENTREPRENEURIAL MIGRATION AS AN INSTRUMENT FOR ENACTING SOCIAL INFLUENCES}

Immigrants are known for being more entrepreneurial than native-born citizens (Kerr \& Kerr, 2018). Most recent analyses have shown that the founders of high-growth ventures, who make a disproportionate contribution to the creation of net new jobs, the generation of innovations, and the development of economic regions (Henrekson \& Johansson, 2010), are often immigrants (Kauffman Foundation, 2015). In fact, first- and secondgeneration immigrant entrepreneurs have founded more than $40 \%$ of the Fortune 500 companies. Although the precise national ratio of entrepreneurial migrants and natives may vary across the economies (Naude, Siegel, \& Marchand, 2017), migrant entrepreneurs are generally known for being less risk averse, as their decision to migrate - a risky activity itself - exemplifies (Neville, Orser, Riding, \& Jung, 2014). Thus, entrepreneurial behavior exhibited by entrepreneurial migrants could be observed by local individuals and serve as a model.

Entrepreneurial migrants represent a very heterogeneous group of people who have moved from one place to another. For the purpose of the present study, three distinct types of entrepreneurial migrants are identified: international, returnee, and regional entrepreneurial migrants. International entrepreneurial migrants are individuals who move from one country to another with the primary goal of launching a business. This group includes transnational entrepreneurs, international entrepreneurs and ethnic entrepreneurs (Drori, Honig, \& Wright, 2009), but only if their relocation abroad was driven by an opportunity to start a new venture as opposed to other economic, educational, humanitarian or relational reasons for migration. Returnee entrepreneurial migrants are individuals who return home after a period of education or business in another country (Drori et al., 2009), and whose decision to relocate is similarly driven by entrepreneurial intentions. Regional entrepreneurial migrants are individuals who move from one region of a country to another in order to start up a business (Niedomysl, Källström, Koster, \& Östh, 2019).

Each of these types of entrepreneurial migrant is characterized by distinctive model characteristics. The model characteristics are relative in nature and compare entrepreneurial migrants with local observers on parameters that are, first, uniform for a particular type of entrepreneurial migrants, and 
second, critical for the provision of social influence from the theory perspective. Together, a set of the model characteristics possessed by a particular type of entrepreneurial migrant will affect the likelihood that observers are exposed to one of the sociopsychological mechanisms of influence presented above and become affected. The present study relies on the assumption that, in order to enact each of the proposed socio-psychological mechanisms, all three types of entrepreneurial migrant should possess more favorable entrepreneurial perceptions and attitudes to entrepreneurship than local individuals. The proposed typology of entrepreneurial migrants, their model characteristics, and the socio-psychological influences they could provide to the local population are presented in Table 1 . Theoretical arguments explaining the attribution of the model characteristics to a particular type of entrepreneurial migrant and their role in activation of the above-mentioned mechanisms are provided in the rest of this section.

The classic observational learning theory distinguishes between four processes that govern learning through observation of the behavior of others. These are attention, retention, motoric reproduction, reinforcement and motivation (Bandura,
1977). While attentional and retentional processes are critical for the acquisition of information about the new behavior and its consequences, in other words, learning the behavior, the reproduction and motivation processes are critical for its performance. As the present study is focused on mechanisms of change in the entrepreneurial perceptions of individuals, but not on the actual behavior change, only attentional and retentional processes fall under the scope of our interest and guide further theorizing. Thus, when considering the model characteristics important for the engagement of local individuals in the process of observational learning, only the attributes that attract the attention of the observers become important.

Beyond the personal characteristics of the observers, it is their associational preferences that play one of the key roles in acquiring attention (Bandura, 1971). According to the differential association theory (Sutherland et al., 1992), association is determined by the frequency, intensity, duration, and priority of social interaction. More frequent, intense and enduring interactions with observed models contribute to a high degree of attention to their behavior. Priority on interaction, or in other words interaction at an early stage in the

Table 1 Dominant socio-psychological influences enacted by different types of entrepreneurial migrants

\begin{tabular}{|c|c|c|c|}
\hline \multirow{2}{*}{$\begin{array}{l}\text { Type of } \\
\text { entrepreneurial } \\
\text { migrant }\end{array}$} & \multicolumn{3}{|c|}{ Mechanism of socio-psychological influence } \\
\hline & $\begin{array}{l}\text { Observational leaning } \\
\text { (the observed behavior produces change } \\
\text { in perceived behavioral control through } \\
\text { observed behavioral outcomes) }\end{array}$ & $\begin{array}{l}\text { Cognitive dissonance } \\
\text { (the observed behavior } \\
\text { produces an internally } \\
\text { justified attitude change) }\end{array}$ & $\begin{array}{l}\text { Social comparison } \\
\text { (exposure to the attitudes of others } \\
\text { produces attitude change through } \\
\text { informational conformity or persuasion) }\end{array}$ \\
\hline International & $\begin{array}{l}\text { - Power over potential future resources } \\
\text { (international business networks) }\end{array}$ & $\begin{array}{l}\text { - Unconventionality of the } \\
\text { observed behavior }\end{array}$ & $\begin{array}{l}\text { Evaluating motive } \\
\text { - Expertise (foreign market knowledge) } \\
\text { - Expertise (entrepreneurial experience) }\end{array}$ \\
\hline Returnee & $\begin{array}{l}\text { - Local personal and business networks } \\
\text { (interaction frequency) } \\
\text { - Shared language (interaction intensity) } \\
\text { - Shared co-national background } \\
\text { (interaction intensity) } \\
\text { - Power over potential future resources } \\
\text { (international business networks) }\end{array}$ & $\begin{array}{l}\text { - Unconventionality of the } \\
\text { observed behavior }\end{array}$ & $\begin{array}{l}\text { Validating motive } \\
\text { - Expertise (foreign market knowledge) } \\
\text { - Expertise (entrepreneurial experience) } \\
\text { - Shared language (credibility) } \\
\text { - Similarity in attributes not related to the } \\
\text { actual attitude/opinion (shared co- } \\
\text { national background) }\end{array}$ \\
\hline Regional & $\begin{array}{l}\text { - Shared language (interaction intensity) } \\
\text { - Shared co-national background } \\
\text { (interaction intensity) }\end{array}$ & & $\begin{array}{l}\text { Validating motive } \\
\text { - Potential expertise (entrepreneurial } \\
\text { experience) } \\
\text { - Shared language (credibility) } \\
\text { - Similarity in attributes not related to the } \\
\text { actual attitude/opinion (shared co- } \\
\text { national background) }\end{array}$ \\
\hline
\end{tabular}


development of the individual (e.g., childhood or young adulthood), also attracts more attention. In the observation of the behavior of entrepreneurial migrants, the highest frequency of interaction with local individuals could be achieved by the returnee entrepreneurs, due to their embeddedness in local personal and business networks. Earlier studies have shown that returnee entrepreneurs are most likely to relocate to places in their home country where they could better tap into the social capital of their domestic networks (Obukhova, Wang, and Li, 2013) or have strong emotional ties (Williams \& Efendic, 2019). Compared with returnee entrepreneurs, international and regional entrepreneurial migrants who do not have historical association with the region they have migrated to are less structurally embedded and thus have fewer opportunities for frequent interaction with local individuals. The highest intensity of interaction with local observers would in turn be exhibited by both returnee and regional entrepreneurial migrants due to their ability to communicate in the local language. Research in socio-linguistics has shown that perceived language similarity is strongly associated with the credibility and competence of the observed models, which in turn attract the attention of observers (Aune \& Kikuchi, 1993). The intensity of interaction could also be affected by other, non-linguistic similarities between the returnee and regional entrepreneurial migrants and the local individuals, such as A shared co-national background. This basis for association may include shared knowledge structures, behavioral patterns, or cultural beliefs.

In addition to associational preferences that focus attention on observational learning, the possession of power also acts as a determinant of attentional commitment, according to the foundational work of Bandura (1977). Power over future resources strongly reinforces attention and consequently reproduction of the observed behavior. Both international and returnee entrepreneurs possess a distinctive resource differentiating them from regional entrepreneurial migrants, namely their international business networks (Filatotchev, Liu, Buck, \& Wright, 2009; Williams \& Efendic, 2019). Access to these networks could significantly affect the initiation, international expansion, and performance of the businesses established by local individuals (Kenney, Breznitz, \& Murphree, 2012). The gatekeeping role of international and returnee entrepreneurs could therefore be seen as a source of power over the future resources of local observers and contribute to attracting their attention.
As opposed to the importance of association through shared co-national background in the process of observational learning, differences in behavioral patterns caused by the foreign background of international and returnee entrepreneurial migrants are the principal factors in the cognitive dissonance perceived by local observers. These both groups of migrants have international experience often gained from exposure to developed and stable economies, where they have also obtained skills and networks beneficial for engagement in entrepreneurial behavior (Williams \& Efendic, 2019). A high degree of unconventionality in the observed behavior contributes to the ratio between dissonant and consonant cognitions and increases the magnitude of the experienced dissonance (Zimbardo \& Leippe, 1991). The high degree of cognitive dissonance increases the need to restructure the cognitions of individuals and increases the likelihood of attitude change. Thus, both the international and returnee entrepreneurial migrants are more likely to provoke change in attitudes to entrepreneurship among local observers than regional entrepreneurial migrants.

The foreign background of the international and returnee entrepreneurial migrants will also play an important role in the mechanism of social comparison. Conformity driven by informational influence depends on the perceived expertise and credibility of the models with whom the opinions and attitudes are compared (Festinger, 1954). The foreign market knowledge available to the international and returnee entrepreneurial migrants makes them seem to be international business experts, particularly in situations where local observers aim to establish an international new venture. This expert status could be even further strengthened by the earlier entrepreneurial experience of international and returnee entrepreneurs, as their act of migration with the primary goal of launching a business is usually preceded by domestic validation of their idea, if not full-fledged earlier entrepreneurial experience.

In addition to the perceived level of expertise, the motives of the observers guiding the need for comparison play a critical role in the mechanism of social comparison. The two motives behind this need are validation and evaluation (Kruglanski \& Mayseless, 1987). While the validation motive makes individuals look for information that provides them with the comfort of being correct, the evaluation motive encourages them to find out whether the opinion or attitude in question is in fact valid. This distinction leads to a tendency to 
look for validating comparisons with similar models and to evaluate comparisons with those who are unalike. As noted earlier, returnee and regional entrepreneurial migrants share a linguistic as well as a broader co-national background with local individuals. Thus, both types of entrepreneurial migrants are more likely to serve as objects of comparison under the condition of validating motivation. In contrast, international entrepreneurial migrants, distinctive in their national, linguistic, and other dissimilar background characteristics, are more likely to serve as objects of comparison under the condition of evaluation motivation.

In sum, observation of the behavior of returnee entrepreneurial migrants acts as a reliable driver of attitude and perceived behavioral control changes across all mechanisms of socio-psychological influence. Exposure to the behaviors and attitudes of international entrepreneurs acts in turn as an efficient driver of unconventional attitudes and innovative behavior. It has been suggested that modeling of such attitudes and behaviors contributes to further diffusion of creative thought and innovation in the society (Bandura, 2016).

The proposed theoretical arguments have explained the attribution of the model characteristics to particular types of entrepreneurial migrants. They have further conceptualized the role of distinctive types of entrepreneurial migrants in activation of the respective socio-psychological mechanisms of change in the entrepreneurial perceptions of local individuals. These theoretically derived arguments outlining the opportunities to stimulate entrepreneurial ecosystems by leveraging micro-level social influences produced by migrant entrepreneurs could serve as a reliable basis for further development of practical tools for policy intervention. Although this task lies beyond the scope of the present study, the next section provides a discussion of several practical considerations related to application of the proposed theorization for social change.

\section{LIMITATIONS AND POLICY CONSIDERATIONS}

Development of the theoretical idea that sociopsychological influences enacted by exogenous policy intervention can be used to shift entrepreneurial perceptions of individuals substantially extends the theoretical reasoning that guides stimulation of entrepreneurial ecosystems through public policy intervention. However, any large-scale social change requires the presence of three complementary systems: theoretical, implementable, and diffusional. The theoretical system develops reliable principles of change as exemplified by the present study. The implementable system translates them into effective practice, while the diffusional system adapts the successful practices in different situational settings. Thus, the theorization proposed in the present study needs to be further supplemented by the actual implementation strategy of the suggested mechanism of social influence. A few broad considerations related to this matter are provided below.

\section{When are the Proposed Mechanisms of Socio- psychological Influence Not Likely to Work?}

The present study is based on the assumption that local individuals exposed to the behavior and attitudes of entrepreneurial migrants have a neutral position on the continuum between resistance and vulnerability to attitude and perception change. An increase in their vulnerability to socio-psychological influences will reinforce the theoretical arguments presented in this study. A decrease (i.e., an increase in resistance) may, however, add predictable complexity to the proposed theorizing. Two factors mostly explain the resistance of individuals to attitude and perception change: the strength of their cognitive structures and their motivation (Zimbardo \& Leippe, 1991). The first factor is related to the willingness of individuals to look for information that conforms to their existing beliefs, to selectively memorize favorable information, and to believe in the information even if it has been discredited. The second motivational basis of resistance is associated with the willingness of individuals to either (re)construct or to validate their existing attitudes and perceptions. The openness to (re)construction of cognitive structures is defined by the relevance of the outcome of change, the public impression caused by the change, the involvement of important values in the change process, and the relevance of the change for the closest social ties of the individual. Awareness of the presence of these drivers of change resistance could guide adjustments in the practices of sociopsychological influences and improve the results of the policy intervention.

\section{What Practical Tools Could Be Used for Implementation of the Proposed Policy Intervention?}

Several governments have recently launched ambitious selective immigrant entrepreneurship 
programs to attract entrepreneurial individuals willing to start a high-growth business abroad (Smale, 2015). The most recent examples of these initiatives are the French Tech Ticket (2016), Startup Estonia (2017), and the Finnish Startup Permit (2018). These initiatives have the primary goal of stimulating economic growth in societies welcoming selective entrepreneurial migration. A simultaneous broader socio-economic impact of these programs on the development of entrepreneurial ecosystem and society at large could, however, be achieved through integration of the proposed principles of socio-psychological influence in the existing policy design. Three guiding principles of policy adjustment need to be taken into account in this case. First, the migrants selected for participation in the entrepreneurship programs need to possess more favorable perceptions and attitudes to entrepreneurship than local individuals. As the opportunity perceptions of entrepreneurial migrants are contextualized in a particular location, the public policy needs to ensure global competitiveness of the local institutional environment for entrepreneurship and related entrepreneurial migration policies in order to be able to attract entrepreneurial migrants to the economy. Second, the programs should ensure opportunities and ensure frequent and intensive interaction between representatives of social groups with distinctively different behaviors and attitudes to entrepreneurship. Third, all types of entrepreneurial migrants participating in these programs should be actively and publicly supported in their entrepreneurial efforts, which would indicate that their behavior has a high perceived functional value and serves to reinforce changes in perception and attitude on the part of local individuals.

\section{How Can the Outcomes of the Proposed Socio- psychological Influence Be Measured?}

As the idea that the socio-psychological influences of entrepreneurial migrants enacted by exogenous policy intervention can be used as a mechanism to shift entrepreneurial perceptions of individuals is still theoretical in nature, its empirical validation should be conducted as the next step. Measurement of the proposed social influence would require careful consideration of suitable research designs. First, empirical testing using the system dynamic simulation approach is suggested. Simulation as an instrument for advancing a theory can overcome the limitations of classic approaches in which accurate measurement of the complex relationships and attribution of causality might be problematic. Second, empirical findings obtained from simulation analysis could be used in the design of a natural policy experiment in which actual entrepreneurial migrants and local individuals would be exposed to each other. The conditions of the natural experiment need to ensure that the causality between the social influence and the change of attitudes and perceptions could be inferred. For this, an unambiguous treatment (policy intervention) condition needs to be selected in order not to fall into the trap of confounding the treatment with other social influences perceived from outside the experimental setting. In addition, a comparison group similar to the treatment group in all aspects except the intervention needs to be utilized. Finally, the distinctiveness of the perceptions and attitudes to entrepreneurship between the targets of the experiment (the local individuals) and the models (the entrepreneurial migrants) needs to be ensured.

The next section concludes the study by highlighting the policy implications of the proposed conceptualization of the socio-psychological impact of entrepreneurial migrants on the entrepreneurial perceptions of the local population in the host country.

\section{CONCLUSIONS}

This study provides three main contributions. First, from the policy perspective, the proposed adoption of the findings from the field of social psychology on social influences in cross-border entrepreneurial migration policy research substantially extends the theoretical reasoning guiding stimulation of entrepreneurial ecosystems through public policy intervention. Use of the socio-psychological influences of migrant entrepreneurs can provide policymakers with a novel mechanism to induce change in the entrepreneurial perceptions and attitudes, which were earlier considered to be least affected by external public policy interventions.

Second, from the perspective of entrepreneurship and international business literature, the study extends the discussion of opportunity perception in the cross-border context. The understanding of the socio-psychological mechanisms of influence in cross-border entrepreneurial migration opens up two new avenues for influencing opportunity perceptions of individuals by public policy. First, it enables policymakers to purposefully design crossborder entrepreneurial migration initiatives in a 
way which would support frequent, intense, and durable interaction between entrepreneurial migrants and the local population. This in turn would enable the shifting of entrepreneurial perceptions of the local population in the locations where perceptions of risk, lack of trust, or institutional dynamism and underdevelopment act as barriers to entrepreneurial activity. Second, following the logic of change of entrepreneurial perceptions of the local population, the sociopsychological mechanisms of influence could enable public policy to shift entrepreneurial perceptions of the migrant entrepreneurs themselves in cases when harnessing their entrepreneurial intentions abroad is challenged by unfavorable perceptions of the institutional environment for entrepreneurship. Purposefully designed interaction of migrant entrepreneurs, particularly diaspora entrepreneurs and returning migrants, with successful investors and/or those who have moved back to the home country to start up a business would initiate perception change and help resolve the challenges of attraction of entrepreneurial talent from abroad.

Third, from the perspective of immigrant entrepreneurship literature, the proposed conceptualization of the impact and the role of migrant entrepreneurs in the economic life of the host countries go beyond the contemporary view, which focuses on narrow labor and capital market perspectives and largely ignores the broader socioeconomic impact of migrant entrepreneurs on entrepreneurial ecosystem development and

\section{REFERENCES}

Ajzen, I. 1985. From intentions to actions: A theory of planned behavior. In J. Kuhl \& J. Beckmann (Eds), Action-control: From cognition to behavior: 11-39. Heidelberg: Springer.

Ajzen, I. 1991. The theory of planned behavior. Organizational Behavior and Human Decision Processes, 50(2): 179-211.

Aldrich, H. E., \& Waldinger, R. 1990. Ethnicity and entrepreneurship. Annual Review of Sociology, 16: 111-135.

Arenius, P., \& Minniti, M. 2005. Perceptual variables and nascent entrepreneurship. Small Business Economics, 24(3): 233-247.

Audretsch, D., Grilo, I., \& Thurik, R. 2007. Explaining entrepreneurship and the role of policy: A framework. In D. B. Audretsch, I. Grilo, \& R. Thurik (Eds), Handbook of research on entrepreneurship policy: 1-17. Northampton, MA: Edward Elgar.

Aune, R. K., \& Kikuchi, T. 1993. Effects of language intensity similarity on perceptions of credibility relational attributions, and persuasion. Journal of Language and Social Psychology, 12(3): 224-238.

Bandura, A. 1971. Social learning theory. New York: General Learning Press. society overall. By adding a social dimension to the analysis of impact produced by migrant entrepreneurship, the present research complements and advances the findings of economists, and answers the newly emerged call to offer alternative theoretical views and address social context of entrepreneurial migration (Thai \& Turkina, 2013; Neville et al., 2014). The proposed theory expands the socio-economic role of migrant entrepreneurs from that of job creators (Kerr \& Kerr, 2018; Kauffman Foundation, 2015), capital investors (Flisi \& Murat, 2011; Mullings, 2011), knowledge providers (Levin \& Bernard, 2013), and institutional change agents (Williams, 2018) to socio-psychological role models who are able to stimulate micro-level changes in the entrepreneurial perceptions and attitudes of local individuals. The conceptual ideas proposed in the study could serve as a theoretical basis for the development of applied policy tools for policy intervention through entrepreneurial migration.

\section{ACKNOWLEDGEMENTS}

The author would like to thank the Editorial team of the Journal of International Business Policy and the two anonymous reviewers for the valuable critical comments they provided. The author gratefully acknowledges the financial support of the present study provided by the Academy of Finland within a postdoctoral research project entitled "The Social Nature of Economic Impact of Policy Induced Expatriate Entrepreneurship".

Bandura, A. 1977. Social learning theory. Englewood Cliffs, NJ: Prentice Hall.

Bandura, A. 2016. The power of observational learning through social modeling. In R. Stenberg, S. T. Fiske, \& D. J. Foss (Eds), Scientists making a difference: 235-239.

Contin-Pilart, I., \& Larraza-Kintana, M. 2015. Do entrepreneurial role models influence the nascent entrepreneurial activity of immigrants? Journal of Small Business Management, 53(4): 1146-1163.

Coviello, N. E. 2006. The network dynamics of international new ventures. Journal of International Business Studies, 37(5): 713731.

Drori, I., Honig, B., \& Wright, M. 2009. Transnational entrepreneurship: An emergent field of study. Entrepreneurship Theory and Practice, 33(5): 1001-1022.

Eberhart, R. N., Eesley, C. E., \& Eisenhardt, K. M. 2017. Failure is an opinion: Institutional change, entrepreneurial risk, and new firm growth. Organization Science, 28(1): 93-112.

Efendic, N. 2016. Expatriate Entrepreneurship: The role of accelerators in network formation and resource acquisition. Doctoral Dissertation, Stockholm School of Economics, Sweden. 
Ellis, P. D. 2011. Social ties and international entrepreneurship: Opportunities and constraints affecting firm internationalization. Journal of International Business Studies, 42(1): 99-127.

Festinger, L. 1954. A theory of social comparison processes. Human Relations, 7(2): 117-140.

Filatotchev, I., Liu, X., Buck, T., \& Wright, M. 2009. The export orientation and export performances of high technology SMEs in emerging markets: The effects of knowledge transfer by returnee entrepreneurs. Journal of International Business Studies, 40(6): 1005-1021.

Fishbein, M., \& Ajzen, I. 1975. Belief, attitude, intention, and behavior: An introduction to theory and research. Reading, MA: Addison-Wesley.

Fishbein, M., \& Ajzen, I. 2010. Predicting and changing behavior: The reasoned action approach. New York: Taylor \& Francis.

Flisi, S., \& Murat, M. 2011. The hub continent? Immigrant networks, emigrant diasporas and FDI. Journal of SocioEconomics, 40(6): 796-805.

Gamlen, A. 2014. Diaspora institutions and diaspora governance. International Migration Review, 48(1): 180-217.

Henrekson, M., \& Johansson, D. 2010. Gazelles as job creators: A survey and interpretation of the evidence. Small Business Economics, 35(2): 227-244.

Hiatt, S. R., Sine, W. D., \& Tolbert, P. S. 2009. From pabst to Pepsi: The deinstitutionalization of social practices and the creation of entrepreneurial opportunities. Administrative Science Quarterly, 54(4): 635-667.

Hsu, D. K., Burmeister-Lamp, K., Simmons, S. A., Foo, M.-D., Hong, M. C., \& Pipes, J. D. 2019. "I know I can, but I don't fit": Perceived fit, self-efficacy, and entrepreneurial intention. Journal of Business Venturing, 34(2): 311-326.

lurkov, V., \& Benito, G. R. G. 2018. Domestic alliance networks and regional strategies of MNEs: A structural embeddedness perspective. Journal of International Business Studies, 49(8): 1033-1059.

Johanson, J., \& Mattsson, L.-G. 1988. Internationalization in industrial systems - a network approach. In N. Hood \& J.-E. Vahlne (Eds), Strategies in global competition: 303-321. New York: Croom Helm.

Johanson, J., \& Vahlne, J.-E. 2009. The Uppsala internationalization process model revisited: From liability of foreignness to liability of outsidership. Journal of International Business Studies, 40(9): 1411-1431.

Kacperczyk, A. J. 2013. Social influence and entrepreneurship: The effect of university peers on entrepreneurial entry. Organization Science, 24(3): 664-683.

Kauffman Foundation. 2015. The economic case for welcoming immigrant entrepreneurs. http://www.kauffman.org/whatwe-do/resources/entrepreneurship-policy-digest/theeconomic-case-for-welcoming-immigrant-entrepreneurs. Accessed 07 October 2019.

Kautonen, T., Tornikoski, E. T., Kibler, E. 2011. Entrepreneurial intentions in the third age: The impact of perceived age norms. Small Business Economics, 37(2): 219-234.

Kenney, M., Breznitz, D., \& Murphree, M. 2012. Coming back home after the sun rises: Returnee entrepreneurs and growth of high tech industries. Research Policy, 42(2): 391-407.

Kerr, S. P., \& Kerr, W. 2018. Immigrant entrepreneurship in America: Evidence from the survey of business owners 2007 \& 2012. National Bureau of Economic Research, Working paper 24494. http://www.nber.org/papers/w24494.pdf. Accessed 07 October 2019.

Krasniqi, B.A., \& Williams, N. 2018. Migration and intention to return: entrepreneurial intentions of the diaspora in postconflict economies. Post-communist Economies, https://doi. org/10.1080/14631377.2018.1505696.

Kruglanski, A. W., \& Mayseless, O. 1987. Motivational effects in the social comparison of opinions. Journal of Personality and Social Psychology, 53(5): 834-842.

Lerner, J. 2012. Boulevard of broken dreams. New Jersey: Princeton University Press.
Levin, D. Z \& Barnard, H. 2013. Connections to distant knowledge: Interpersonal ties between more- and less-developed countries. Journal of International Business Studies, 44(7): 676-698.

Liang, J., Wang, H., \& Lazear, E. P. 2016. Demographics and entrepreneurship. National Bureau of Economic Research, Working paper 20506. http://www.nber.org/papers/ w20506.pdf. Accessed 07 October 2019.

Lundström, A., \& Stevenson L. A. 2005. Entrepreneurship policy: Theory and practice. International studies in entrepreneurship. New York: Springer.

Manolova, T. S., Manev, I. M., \& Gyoshev, B. S. 2010. In good company: The role of personal and inter-firm networks for new-venture internationalization in a transition economy. Journal of World Business, 45(3): 257-265.

Mayer, S. D., Harima, A., \& Freiling, J. 2015. Network benefits for Ghanaian Diaspora and returnee entrepreneurs. Entrepreneurial Business and Economics Review, 3(3): 95-122.

McMillan, G. S., Narin, F., \& Deeds, D. L. 2000. An analysis of the critical role of public science in innovation: The case of biotechnology. Research Policy, 29(1): 1-8.

McMullen, J. S., \& Shepherd, D. A. 2006. Entrepreneurial action and the role of uncertainty in the theory of the entrepreneur. Academy of Management Review, 31(1): 132-152.

Mullings, B. 2011. Diaspora strategies, skilled migrants and human capital enhancement in Jamaica. Global Networks, 11(1): 24-42.

Nanda, R., \& Sørensen, J. B. 2010. Workplace peers and entrepreneurship. Management Science, 56(7): 1116-1126.

Naude, W. Siegel, M., \& Marchand, K. 2017. Migration, entrepreneurship and development; critical questions. IZA Journal of Migration, 6: 1-16. https://doi.org/10.1186/ s40176-016-0077-8.

Neville, F., Orser, B., Riding, A., \& Jung, O. 2014. Do young firms owned by recent immigrants outperform other young firms? Journal of Business Venturing, 29(1): 55-71.

Newman, A., Obschonka, M., Schwarz, S., Cohen, M., \& Nielasen, I. 2019. Entrepreneurial self-efficiacy: A systematic review of the literature on its theoretical foundations, measurement, antecedents, and outcomes, and an agenda for future research. Journal of Vocational Behavior, 110(B): 403419.

Niedomysl, T., Källström, J., Koster, S., \& Östh, J. 2019. Interregional migration of business owners: Who moves and how does moving affect firm performance. Regional Studies, 53(4): 503-516.

Nielsen T. M., \& Riddle, L. 2010. Investing in peace: The motivational dynamics of diaspora investment in postconflict economies. Journal of Business Ethics, 89(4): 435-448.

Obukhova, E., Wang, Y., \& Li, J. 2013. The power of local networks: Returnee entrepreneurs, school ties, and firm performance. Academy of Management Proceedings, 23(1).

OECD. 2000. OECD Employment Outlook. https://www.oecdilibrary.org/docserver/empl_outlook-2000-en.pdf?expires= 1535108611 \&id=id\&accname $=$ ocid $177143 \&$ checksum $=$ 1544137C10912724674AE5980EBA5BE2. Accessed 07 October 2019.

Oviatt, B. M., \& McDougall, P. P. 2005. Defining international entrepreneurship and modelling the speed of internationalization. Entrepreneurship Theory and Practice, 29(5): 537-553.

Parsons, T. 1951. The social system, New York: Routledge.

Reuber, A. R., Knight, G. A., Liesch, P. W., \& Zhou, L. 2018. International entrepreneurship: The pursuit of entrepreneurial opportunities across national borders. Journal of International Business Studies, 49(4): 395-406.

Saxenian, A. L. 1999. Silicon Valley's new immigrant entrepreneurs. San Diego: Public Policy Institute of California.

Smale, W. 2015. The global fight to attract foreign entrepreneurs. BBC News. http://www.bbc.com/news/business31602943?ocid=socialflow_twitter. Accessed 22 October 2019. 
Sutherland, E. H., Cressey, D. R., \& Luckenbill, D. F. 1992. Principles of criminology. Oxford: Rowman \& Littlefield.

Thai, M. T. T., \& Turkina, E. 2013. Entrepreneurial migration: Characteristics, causes and effects. Journal of Enterprising Communities: People and Places in the Global Economy, 7(3): 188-195.

Thurik, R., Wennekers, S., \& Uhkander, L. M. 2002. Entrepreneurship and economic performance: A macro perspective. International Journal of Entrepreneurship Education, 1(2): 157-179.

Verheul, I., Wennekers, S., Audretsch, D., \& Thuril, R. 2001. An eclectic theory of entrepreneurship: policies, institutions and culture. Tinbergen Institute Discussion Paper Series, No. TI 2001-030/3. http://hdl.handle.net/1765/6873. Accessed 07 October 2019.

Webb, T. L., \& Sheeran, P. 2006. Does changing behavioral intention engender behavior change? A meta-analysis of the experimental evidence. Psychological Bulletin, 132(2): 249268.

Williams, N. 2018. Mobilising diaspora to promote homeland investment: The progress of policy in post-conflict economies. Environment and Planning C, 36(7): 1256-1279.

Williams, N., \& Efendic, A. 2019. Internal displacement and external migration in a post-conflict economy: Perceptions of institutions among migrant entrepreneurs. Journal of International Entrepreneurship. https://doi.org/10.1007/s10843-01900244-5.

Wilson, F., Kickul, J., \& Marlino, D. 2007. Gender, entrepreneurial self-efficacy, and entrepreneurial career intentions: Implications for entrepreneurship education. Entrepreneurship Theory and Practice, 31(3): 387-406.
Zimbardo, P. G., \& Leippe, M. R. 1991. The psychology of attitude change and social influence. New York: McGraw-Hill.

\section{ABOUT THE AUTHOR}

Daria Kautto (née Volchek) is a postdoctoral researcher in International Business at Aalto University School of Business, Finland, and a postdoctoral fellow of the Academy of Finland. Her research interests include international entrepreneurship, cross-border entrepreneurial migration, and entrepreneurship policy.

Open Access This article is distributed under the terms of the Creative Commons Attribution 4.0 International License (http://creativecommons. org/licenses/by/4.0/), which permits unrestricted use, distribution, and reproduction in any medium, provided you give appropriate credit to the original author(s) and the source, provide a link to the Creative Commons license, and indicate if changes were made.

Publisher's Note Springer Nature remains neutral with regard to jurisdictional claims in published maps and institutional affiliations.

Accepted by Helena Barnard, Area Editor, 7 October 2019. This article has been with the author for three revisions. 